\title{
The Impact of Global Financial Crisis on Health Status in the Chinese Mainland*
}

\author{
Chen Li, Yao Lan, Jiang Hong \\ Economic Management College, Changzhou University, Changzhou, China \\ Email: chenli19860627@sina.com \\ Received April $5^{\text {th }}$, 2013; revised June 26 $6^{\text {th }}$, 2013; accepted July $6^{\text {th }}$, 2013
}

\begin{abstract}
Copyright (c) 2013 Chen Li et al. This is an open access article distributed under the Creative Commons Attribution License, which permits unrestricted use, distribution, and reproduction in any medium, provided the original work is properly cited.
\end{abstract}

\begin{abstract}
Nowadays, globalization increases the integration between countries, leading to the emergence of a global marketplace or a single world market. And, no country or region can develop in self-seclusion. The financial crisis is unprecedented because it comes at a time of radically increased interdependence. What is more, financial turmoil is contagious, moving rapidly from one country to another and spreading very quickly from one economic sector to many others. Since the reform and opening up, China has made remarkable economic achievements. Especially in the economic globalization trend, the financial sector has developed rapidly and its influence on economy is also growing fast. However, along with the rapid development of economy and the outbreak of financial crisis, economic factors play an important role in modern society. Due to the influence of the current global financial and economic crisis, efforts to reach health-related MDGs are confronted with daunting challenges. Public health departments of all countries are faced with increased demand for their services (Liu Zhenmin, 2009), the risk of lower services quality, contraction of financial resources as well as a higher risk of a "brain drain" of health professionals. Hence, this paper aims to analyze the impact of the global recession on the health of people in the Chinese mainland and sum up a series of measures to ensure the steady growth of national economy and safeguard the social harmony and stability.
\end{abstract}

Keywords: Global Recession; Public Health; Financial Crisis; Impact

\section{Introduction}

Since the US subprime mortgage crisis caused falling house prices in 2007, the US economy has suffered a recession risk. United States turned into a source of the most serious global financial crisis since the 1930s. What is more, the mortgage crisis triggered a worldwide financial crisis that spread to the global economy (The research report, 2009). All kinds of signs show that the crisis will not disappear within a short term. For developing countries, the ability to withstand the financial crisis is limited, and their social security system is relatively imperfect. Thus, the financial crisis is becoming a threat to the poor people in developing countries, which means that the social progress there in the past several decades may have been seriously damaged. As a result, the achievement of The Millennium Development Goals (MDGs) is facing enormous challenges.

Compared with the Asian financial crisis in 1998, the impact of this financial crisis over China has the following characteristics (World Bank, 2009): First, the financial crisis originated in the United States, and the range affected by this financial crisis was broader than Asian financial crisis. However, this financial crisis had little effect on the China's economy. Second, China's current dependence on export is higher than that in the past, and the resistance to economic recovery may not only depend on the economic situation. Third, the international investment weakened China's economic strength of enhancing the

"Short paper. ability to deal with the financial crisis. Fourth, China has built up a relatively perfect social security system, including the minimum living security, pension security, medical security system. The system has significantly diminished the likelihood that financial crisis turns into a social crisis.

\section{The Financial Crisis Has a Greater Impact in Export}

At present, the impact of the financial crisis on the processing and manufacturing in the Chinese Mainland is enormous. Its impact cannot be ignored. There have been a lot of problems, such as decline in export trade, slow-down of economic growth, unemployment as well as other macroeconomic issues. Figure $\mathbf{1}$ shows that the financial crisis has a great impact on export.

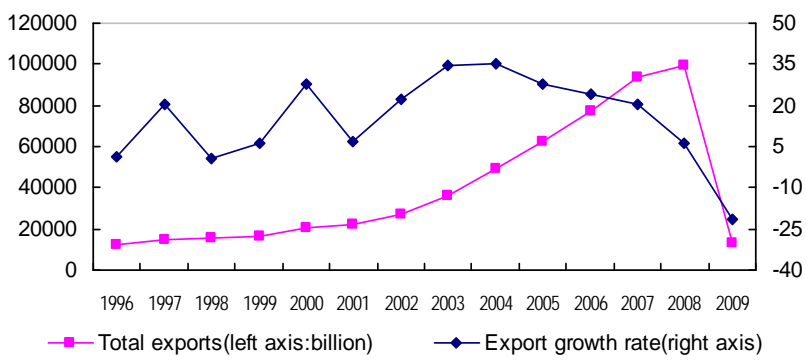

Figure 1.

China's export trade volume changes (\%). 
Specifically, the impact of financial crisis mainly occurred in the export processing enterprises, and then spread to the entire economic system. This financial crisis is different from the financial crisis in 1998, which was caused mainly by the withdrawal of large fund of international short-term liquidity. China is the direct victim. But the Chinese government has a strong U.S. dollar reserve to attract foreign investment by focusing on long-term investment, which helps to better weather the Asian financial. In 2009, the trends of international trade in the Chinese Mainland exhibited a rapid decline. There was, moreover, a $20 \%$ reduction in the monthly export volume compared with that of the same period in the previous year. From the history of the impact of the financial crisis, we learn that the financial crisis had a great impact on the exports. For example, there was stagnation in exports in 1998. And at this time, from the beginning of the second half of 2007, the trend of growth rate kept reducing obviously. In 2008, the export in the mainland of China from January to September was 1.074 trillion US dollars, which was an increase of $22.3 \%$. After deducting price factors, the actual increase of $11.8 \%$, which means 8.1 percentage point less compared with same period in the year before.

\section{Reduction of Tax Leads Revenue to Reduce}

China's revenue has declined in the apparent crisis. Decline in exports was mainly caused by the decrease of corporate profits and related lower tax revenue. In addition, in the fourth quarter of 2008, the government began to implement a proactive fiscal policy in the mainland, which included implementation of structural and tax cut. There were other measures, such as 1) value added restructuring; 2) reform in tax for refined oil; 3) raising the export tax rebate rate; 4) reducing the export tariff and so on. In addition, stamp duty on stock transactions declined significantly, resulting in the decrease in the government's fiscal revenue.

\section{The Financial Crisis Causes to Greater Volatility in Prices}

China's inflation has grown rapidly, especially in food prices in 2008. In response to this financial crisis, the government issued a series of measures, such as infrastructure development and boosting domestic demand, to ensure the steady growth of national economy and safeguard the social harmony and stability. It is worth noting that the government made an economic stimulus plan, namely an investment plan of 4000 trillion Yuan in two years. The government, as it seems, should focus on strengthening social security. It is estimated that the new medical and health reform in the next three years will reach 850 billion investments. Financial crisis has become an opportunity to develop health system in China, accounting for more than $1 / 5$ of the entire economic stimulus package.

\section{The Impact of Global Crises on Health}

The impact of the financial crisis on China's influence cannot be ignored. It can be detected in the decline in export trade, slow-down of economic growth, unemployment, and other macroeconomic issues. Due to the current global financial and economic crisis, public health departments of all countries are facing increased demand for their services, the risk of lower services quality, and contraction of financial resources. And the impact of global crises on health includes different aspects of the following.

\section{A Reduction in Government's Revenue and Its Negative Effects on Public Health Input}

China's revenue suffered during the financial crisis. The decline in exports was mainly caused by reduced corporate profits and lower tax revenue. In addition, the government began to implement a proactive fiscal policy and tax cuts in the fourth quarter of 2008, which, in addition to a series of tax policies, included restructuring value-added tax, refining oil tax reform, raising the export tax rebate rate, reducing the export tariff, provisionally cancelling the transfer of housing business tax. What is more, stamp duty on stock transactions declined significantly, which caused the decrease of the fiscal revenue. Figure 2 shows a slight and gradual decline of the government revenue after the resumption. The decline in 2002 was mainly due to the discharge into the World Trade Organization commitments, which resulted in a decrease of the general tariff from $15.3 \%$ to $12 \%$. In addition, the tax rate in finance and insurance business was lowered in order to stop the implementation of policies of state-owned shares. During the crisis, the growth rate of government revenue declined by nearly 13 percentage points. In 2009, the trends of all periods declined if compared with their counterparts in the previous year. The government was facing enormous pressure on government revenue.

In conclusion, government revenue reduced because of the implementation of economic incentives, which led to the decrease of the growth rate of health budget. As a result, the reduction in international assistance can lead to a decrease in the use of health resources (Hicks \& Wodon, 2000). In addition, the reduction in the prevention of the budget for health services (including high blood pressure, diabetes, AIDS and tuberculosis) may result in the decrease in health services accessibility, equity, and reduced availability. For example, Mexico’s GDP in 1994-1996 fell between 4.6 percent and its population in poverty dropped by government investment of $23.7 \%$ (The research re- port, 2009).

\section{The Impact of Inflation on the Availability and Affordability of Basic Health Services}

Inflation and currency devaluation led to low imports of medical equipment and high medicine prices, which resulted in the decrease of the availability and affordability of health services. In the Asian financial crisis (Pablo, 2009), due to the devaluation of their currencies, some countries had to deal with higher import prices of drugs and some related to medical

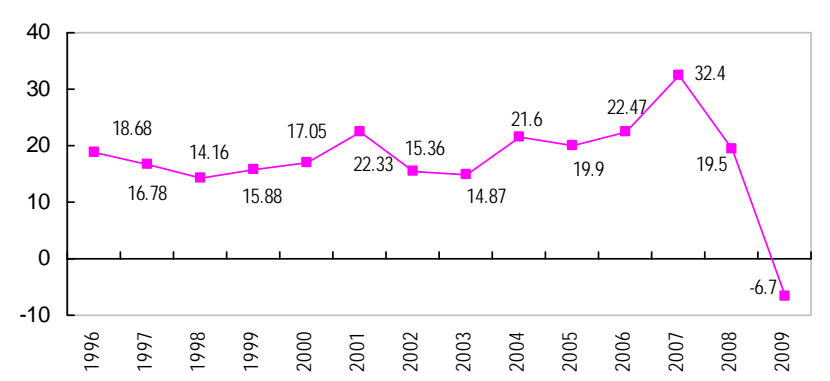

Figure 2.

The government's financial income increases condition (\%). 
devices. This caused an increase of some international prices of medical services, coupled with a reduction of income for their residents. Such circumstances may affect the consumption of medical services and utilization. From Figure 3, we can tell that inflation had grown rapidly in the Chinese Mainland, especially in food prices in 2008 and the prices of medical services in national economic development that were fundamental to maintaining the normal range. The first half of 2008 food prices was 15 percent higher than that in the last year's growth. In February of 2009, there was a negative growth, which continued until June 2009.

\section{Increase in Proportion Payment of Individuals and Its Effect on Inefficient Using of Health Services}

The high costs of health care inflicts heavy financial burden on some people and reduces them to poverty. In some countries, the residents pay the proportion of costs accounted for more than 50\% - 60\% (World Bank, 2008), the financial crisis forced the residents to reduce use of health services. For example, in the financial crisis, the inability to pay medical insurance costs and loss of medical insurance forced the residents minimize the use of preventive health services. According to a survey of Argentina (The research report, 2009), the crisis in 2001-2002 forced $13 \%$ of the families to cancel the medical insurance. In addition, $57 \%$ of households do not have access to preventive health services. What is more, such high payment leads to inefficient use of health services. The overall unemployment rate increased slightly during the crisis.

\section{Lower Real Incomes Led to a Falling Standard of Living and a Negative Impact on Public Health}

Residents lost their jobs, and hence their income and medical insurance. Those people who were in basic livelihood cannot afford to satisfy their need for public health care. And provision of basic nutrition supply and medical care cannot meet people's demand. All of these factors may lead to decline in people's health conditions. It is estimated that shortage in world food supply may cause malnutrition, which may have a negative effect on 44 million people (World Bank, 2009). Figure 4 indicates an increased pressure on current employment and reemployment in the Chinese Mainland. The chart also showed a growth of the unemployment rate in 2000-2003, which was mainly due to reform the state-owned enterprise and the increase of unemployment caused by laid-off workers. In both of the financial crises, those indexes did not change significantly. According to the survey, in 2008 the employment needs in enterprises all over the country and the employment in urban areas dropped on monthly basis. The numbers of new jobs in

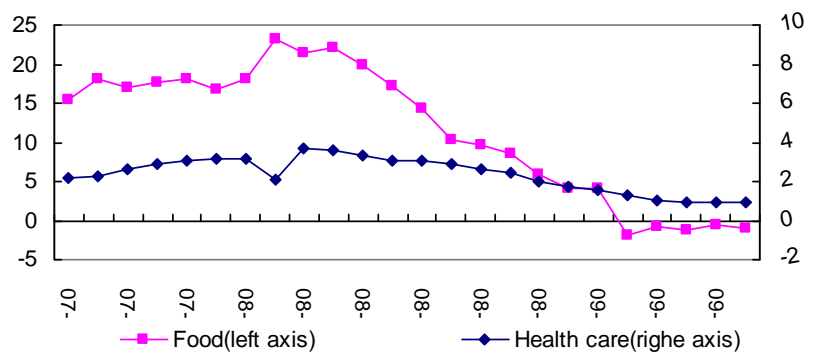

Figure 3.

Index changes (\%) in the prices of food and Health Care Products.

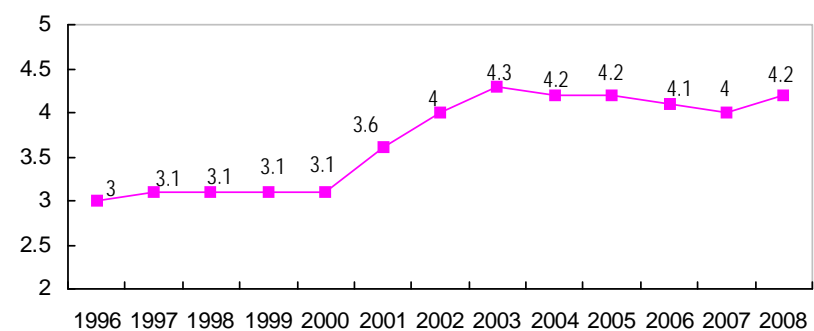

Figure 4.

Registered urban unemployment rate (\%) in the Chinese Mainland.

July were 840,000, 550,000 when there were 38 million college graduates in urban areas. Employment difficulties became more serious (The research report, 2009). This situation is particularly serious in the coastal and export-oriented areas, such as Shenzhen 深圳, Dongguan 东莞 and other places.

In order to response to the financial crisis, the Chinese government has issued a series measures to strengthen the construction of infrastructure and a number of policies to stimulate consumption, which included the investment of 850 billion RMB for the new medical and health system. The main measure is to strengthen the system of grassroots health service to provide free public health services, such as basic drug system and a basic medical insurance system. The aim of all the measures is to provide all residents with a high level of basic medical services.

\section{The Measures to Ease the Health Problems Affected by the Financial Crisis}

The measures to deal with financial crisis include strengthening infrastructure construction, restoration and reconstruction after the earthquake. The central government allocated 908 billion RMB on public investment in 2009 to fund education, health care and other social construction. The plan involved the reduction of some taxes, cancellation of 100 administrative fees and charges, raise of the standards of personal income tax collection, and some other measures. This was expected to reduce the burden of businesses and residents about 5000 billion RMB in 2009 and thereby raise the consumption level of residents (Batniji \& Woods, 2009). It included a series of measures to strengthen social security in the comprehensive economic stimulus plan, such as increasing the input of social security, implementing the new measures of the medical and health system and so on. The government made a timely response to the financial crisis, and it helped to maintain the stability of the economy system and the lives of the residents.

\section{Improving the Living Conditions of Poverty Residents and Protecting the Basic Needs of Life}

In order to improve the living conditions of the poor and meet their basic living needs, the plans included measures to be taken in education, housing, medical care and comprehensive social security measures and so on. The specific measures include the following:

First, improvement of the level of basic education: The government decided on a new provision of 47 billion RMB for compulsory education in rural area, which would make it possible to provide both free textbooks for rural compulsory education and a living allowance to rural students. In response to 
financial crisis (World Health Organization, 2009), it also provided four months' temporary living allowance to college students in 2008.

Secondly, strengthening the housing security system: the plan required that, during 2009 to 2011, the existing housing difficulties of 7.47 million low-income families in urban areas should be basically solved (World Health Statistics, 2012). About 100 billion RMB would be allocated for this purpose within the next three years.

Thirdly, increasing subsidies for low-income groups: The central government invested a total of 146.136 billion RMB for employment, urban and rural development in 2008 (The research report, 2009). The plan had improved the standard of financial subsidy for the people of subsistence allowance twice, once on January 1 , and the other time on July 1,2008 . The standard of compensation in urban was $15 \mathrm{RMB}$ and that in the rural was $10 \mathrm{RMB}$. The total number of financial subsidy reached 36.31 billion RMB (The research report, 2009), which increased the basic pension of enterprise retirees.

Other measures included increasing the constructors of the social security system and community service system, and ensuring proper placement for unemployed migrant workers, and so on. Thanks to the series of measures as part of the reform in social security, the basic living conditions of residents were not affected by the crisis.

\section{The Government's Investment in Basic Medical Insurance Should Be Increased to Reduce the Burden on Resident Effectively}

The investment aims to coordinate the promotion of public health as a response to the financial crisis and effectively guarantee input in public health. On the basis of formulating economic stimulus packages, all countries should prioritize the achievement of health-related MDGs, provide adequate financial guarantee to public health departments, and, wherever possible, minimize the impact of the crisis on poor families. It is also necessary to strengthen policy coordination among various departments, promote social activities, and expand the coverage of public health service system.

In order to enhance the capacity of reducing citizens' economic risks caused by disease, there were also plans to prevent illness and the resultant poverty. According to the spirit of the new medical and health reform, medical insurance systems for staff members and workers, medical insurance systems for resident and new rural cooperative medical systems will cover all residents of urban and rural areas in three years. In addition, insurance rates are increased to $90 \%$.

In order to reduce the burden on individuals, there are following major governmental measures to improve the insurance of health care:

Firstly, expanding the coverage of medical insurance system for resident in cities and towns increases the protected population. In 2008 there would be 229 pilot cities with basic medical insurance system for citizens in cities and towns. Since 2009, the government has endeavored to expand the pilots for medical insurance system for resident in cities and towns in order to include all college students in the medical insurance system, and support the retirees from closed and bankrupted stateowned businesses so they can be included in the basic medical insurance system for staff members and workers in cities and towns.
Secondly, it is important to upgrade the level of government investment. In 2009 the government raised the standard of the new rural cooperative medical care to $80 \mathrm{RMB}$ per capita. Later it reached 120 RMB in 2010 (World Health Statistics Report, 2011). The other plans aimed to reform the compensation method. In 2009 the cap line of new rural cooperative medical (maximum payment limits) was 6 times higher than the local farmers' income per capita.

Thirdly, it is noticeable to increase the standard of urban and rural medical assistance. In 2009 there was 6.45 billion RMB subsiding for medical insurance reimbursement. It still provides second chance of reimbursement for residents, who has heavier burden on normal lives.

Through compensation, health care can greatly reduce the financial burden on individual residents (Sinaha \& Ahmad, 2009). In addition, the first clinic in community and the compensation for out-patient clinics can both minimize the proportion of the burden on individuals wherever possible.

\section{The Importance of Policy Implementation}

In order to make sure the reforms in medical and health care proceed smoothly, the central government has also taken some other measures, which include the following:

1) Legislation for social security. This is to institutionalize a long-term provision of social security and optimize the social security system.

2) Setting up an inter-departmental and co-ordination leading agency, responsible for co-ordinating, organizing and coordinating the work of reform. For example, it establishes a "State Council Leading Group deepening for the medical and health system" in medical and health system reform.

3) Merging some government departments. For example, it puts the State Food and Drug Administration 国家食品药品监 督管理局 into the regulatory jurisdiction of the Ministry of Health 卫生部, and in so doing, improves the coordination of relevant departments and enhances efficiency. And the ministry of health was incorporated into the national health and family planning commission 国家卫生和计划生育委员会 in 2009.

4) Making sure the implementation of health reform is in place. It is expected that all levels of government invest 850 billion RMB for the new medical and health system, of which the central government has invested 331.8 billion RMB.

The central government's measures to unify leadership and the legislature are very important. They ensure a proper functioning of the social security system, a proper implementation of the health reform, and a proper coordination of other measures. Together, they will reduce the impact of the financial crisis on the residents to the minimum.

\section{REFERENCES}

Liu Zhenmin 刘振民 (2009). Statement by Ambassador Liu Zhenmin at the high-level Forum on Advancing Global Health in the face of crisis. 刘振民大使在“在危机面前推动全球卫生事业”论坛上的发 言. http://www.kouyi.org/field/health/857.html

The research report (2009). Study on the impact of the global recession on the health of the people in China. 课题研究报告: 经济危机对中 国居民健康状况的影响研究. WHO.

World Bank (2009). Global Monitoring Report 2009.

Hicks, N., \& Wodon, Q. (2000). "Economic Shocks, Safety Nets, and Fiscal Constraints: Social Protection for the Poor in Latin America,” 
CHEN L. ET AL.

The XII Seminario Regional de Political Fiscal, Santiago.

Pablo, G. et al. (2009). Protecting pro-poor health services during financial crises lessons from experience1.

World Bank (2008). rising food and fuel prices: Risks to future generations.

Batniji, R., \& Woods, N. (2009). Averting a crisis in global health: 3 Actions for the G20.

World Health Organization (2009). Report on the impact of the global recession on the health of the people in China.
World Health Statistics (2012).

http://www.who.int/gho/publications/world_health_statistics/2012/en /index.html

World Health Statistics Report (2011).

http://www.who.int/whosis/whostat/2011/en/

Sinaha, S. K., \& Ahmad, Z. (2009). Ahmad global financial crisisWith special reference to insurance industry. African Journal of Marketing Management, 1, 184-189. 